\title{
AKTIVITAS EKSTRAK ETANOL 96\% KULIT BIJI MELINJO (Gnetum gnemon) SEBAGAI ANTIBAKTERI Salmonella enteritidis
}

\author{
Ade Kusmiati ${ }^{1}$, Tri Saptari Haryani ${ }^{1}$, Triastinurmiatiningsih ${ }^{1 *}$ \\ ${ }^{1}$ Program Studi Biologi FMIPA Universitas Pakuan, Bogor \\ *e-mail: triastinur@gmail.com
}

diterima: 20 Februari 2019; direvisi: 2 Maret 2019; disetujui: 30 Maret 2019

\begin{abstract}
ABSTRAK
Kontaminasi Salmonella enteritidis pada daging ayam menyebabkan daging ayam cepat mengalami pembusukan. Penggunaan pengawet kimia sangat membahayakan, maka dari itu penggunaan bahan alami sangat dianjurkan karena lebih aman dikonsumsi bagi manusia. Salah satunya adalah menggunakan kulit biji melinjo yang memiliki daya antibakteri. Penelitian ini berujuan dari untuk mengetahui aktivitas ekstrak kulit biji melinjo dalam menghambat pertumbuhan Salmonella enteritidis yang dapat digunakan sebagai pengawet alami pada daging ayam. Tahap pertama yang dilakukan pada penelitian ini adalah dengan mengekstrak kulit biji melinjo menggunakan etanol 96\% dengan metode maserasi selama 6 hari. Uji aktivitas ekstrak kulit biji melnjo terhadap Salmonella enteritidis menggunakan metode kertas cakram dengan variasi perlakuan $25 \%, 50 \%, 75 \%$ dan kontrol positif tetrasiklin. Parameter yang diamati adalah pengukuran Diameter Daerah Hambat (DDH) dan uji fitokimia terhadap ekstrak kulit biji melinjo. Hasil penelitian untuk pengujian Diameter Daerah Hambat (DDH) didapat konsentrasi yang paling efektif yaitu pada konsentrasi $75 \%$ dengan diameter daerah hambat sebesar 10,3 $\mathrm{mm}$ dan dikategorikan mempunyai daya antimikroba tingkat sensitifitas sedang serta dapat dijadikan pengawet alami pada daging ayam. Hasil uji fitokimia menunjukkan adanya kandungan senyawa flavonoid, tannin, saponin dan triterpenoid.
\end{abstract}

Kata Kunci: Kulit biji melinjo, Salmonella enteritidis, antibakteri

\section{ACTIVITY of ETHANOL EXTRACT 96\% SEED BARK MELINJO (Gnetum gnemon) AS a Salmonella enteritidis ANTIBACTERIAL}

\begin{abstract}
Salmonella enteritidis contamination in chicken meat causes chicken meat to rapidly decay. The use of chemical preservatives is very harmful, therefore the use of natural materials is recommended because it is safer to consume for humans. One of them is using Melinjo seed skin which has antibacterial power. The purpose of the study is to find out the activity of Melinjo seed bark extract (Gnetum gnemon) in inhibiting the growth of Salmonella enteritidis that can be used as a natural preservative in chicken meat. The first stage of the study was by extracting Melinjo seed bark using ethanol 96\% with maceration method for 6 days. Activity test of Melnjo seed bark extract against Salmonella enteritidis using method of disc paper with a variation of the treatment of $25 \%, 50 \%, 75 \%$ and tetracycline positive control. The observed parameter is the measurement of the inhibited region Diameter (DDH) and the phytochemical test against Melinjo seed bark extract. The research results for the testing of the area Diameter of the hhibited region obtained the most effective concentration of $75 \%$ in the diameter of the area of the barrier of $10.3 \mathrm{~mm}$ and categorized with antimicrobial power levels of moderate sensitivity as well as can be used as natural preservatives in chicken meat. Phytochemical test results indicate the presence of compound flavonoids, tannins, saponins and triterpenoid.
\end{abstract}

Key words: Melinjo seed skin, Salmonella enteritidis, antibacterial 


\section{PENDAHULUAN}

Salmonella enteritidis adalah bakteri yang tak terpisahkan dari manusia karena habitat utamanya berada pada saluran pencernaan manusia. Salmonella enteritidis juga merupakan penyebab terjadinya penyakit salmonellosis dan gangguan pada bagian saluran pencernaan atau gastroenteritis, dengan cara mengkontaminasi telur atau daging ayam yang dikonsumsi oleh manusia (Ariyanti dan Supar, 2005). Kontaminasi Salmonella pada daging ayam menyebabkan daging ayam cepat mengalami pembusukan karena daging ayam memiliki kadar air yang tinggi yaitu sekitar $75 \%$. Selain itu juga daging ayam cepat terkontaminasi bakteri pada proses pemotongan (Rahardjo, 2012). Untuk menekan pertumbuhan bakteri Salmonella, umunya daging ayam disimpan dengan berbagai cara seperti: pendinginan, pembekuan, proses termal (pemanasan), dehidrasi (pengeringan), atau dengan pengawetan menggunakan bahan-bahan pengawet seperti garam, gula, asam, dan berbagai pengawet sintetis atau pengawet kimia (Usmiati, 2010). Penggunaan pengawet kimia seperti formalin, asam borat, asam salisilat, kalium klorat, kloramfenikol, dan lain-lain sangat membahayakan, apabila dikonsumsi oleh manusia. Maka dari itu penggunaan bahan alami sangat dianjurkan karena lebih aman dikonsumsi bagi manusia. Salah satunya adalah menggunakan kulit biji melinjo yang memiliki daya antibakteri.

Tanaman melinjo (Gnetum gnemon) merupakan tanaman yang sering dipakai untuk bahan makanan, mulai dari daun, bunga maupun biji. Selain itu juga menghasilkan senyawa antioksidan serta mengandung antimikroba alami, artinya protein melinjo juga bisa dipakai sebagai pengawet alami makanan (Mukhlisah, 2014).

Kulit biji melinjo yang berwarna merah memiliki berbagai macam komponen atau senyawa yang berguna bagi tubuh dan dapat digunakan sebagai pewarna makanan alami. Komponen atau senyawa di dalam kulit biji melinjo yang berwarna merah adalah fenolik, flavonoid, likopen, vitamin $\mathrm{C}$, dan $\beta$-karoten. Sifat dari kulit biji melinjo yang berwarna merah dapat digunakan sebagai pewarna alami karena memiliki pigmen likopen dan $\beta$-karoten (Siregar $d k k$, 2009). Pada umumnya daging ayam yang dijual dipasar memiliki warna daging yang pucat, maka dari itu penggunaan kulit biji melinjo merah ini dimaksudkan agar tampilan dari daging ayampun telihat lebih segar dan alami.

\section{BAHAN DAN METODE Bahan}

Kulit biji melinjo yang sudah tua (berwarna merah) segar diperoleh dari Desa Ragemanunggal Kec. Setu, Bekasi. Kulit biji melinjo dikeringkan dalam oven pada suhu $60^{\circ} \mathrm{C}$ selama $2 \times 24$ jam kemudian digiling hingga menjadi serbuk dan disaring.

Bakteri yang dipakai dalam penelitian ini adalah kultur Salmonella enteritidis.

\section{Metode \\ Pembuatan Ekstrak Kulit Biji Melinjo (Silaban, 2009)}

Serbuk kulit melinjo sebanyak 300 g diekstraksi dengan metode maserasi selama 6 hari dengan nisbah sampel: etanol 96\% sebesar 1:10 sambil sesekali diaduk. Dengan cara 300 gr serbuk kulit biji melinjo dimaserasi dengan etanol $96 \%$ sebanyak $2250 \mathrm{ml}$ selama $3 \times 24$ jam, kemudian disaring dengan menggunakan kertas saring dan bantuan vacum flask, filtrat di tampung dalam Erlenmeyer (filtrat I). Residu yang diperoleh direndam kembali dengan $750 \mathrm{ml}$ etanol 96\% selama 3x24 jam. Kemudian hasil rendaman disaring kembali dan didapatkan filtrat II. Setelah itu filtrat I dan filtrat II disatukan dan dievaporasi dengan menggunakan rotary evaporator pada suhu $55^{\circ} \mathrm{C}$ sampai tidak terjadi lagi pengembunan pelarut pada kondensor sehingga diperoleh ekstrak kental.

\section{Analisis Kadar Air}

Cawan porselen dikeringkan menggunakan oven pada suhu $105^{\circ} \mathrm{C}$ selama 1 jam 
kemudian didinginkan ke dalam desikator selama 15 menit dan ditimbang bobotnya. Sampel ditimbang menggunakan neraca analitik 1-2 g dan dimasukkan kedalam oven dengan suhu $105^{\circ} \mathrm{C}$ selama $3 \mathrm{jam}$. Kemudian sampel didinginkan didalam desikator selama 20 menit dan ditimbang bobotnya. Rumus \% Kadar air sebagai berikut:

$$
\% \text { Kadar Air }=\frac{\mathrm{A}+\mathrm{B}-\mathrm{D}}{\mathrm{B}} \times 100 \%
$$

\section{Persiapan Bakteri Uji}

Bakteri Salmonella enteritidis disubkultur pada agar miring Nutrient Agar (NA) kemudian diinkubasi selama 24 jam pada suhu $37^{\circ} \mathrm{C}$. Setelah masa inkubasi, bakteri dipanen dengan cara menambahkan aquades steril dan mengkikis permukaan agar miring dengan ose kemudian dimasukan kedalam tabung dan dijadikan sebagai stok. Untuk membuat larutan $10^{-1}$ dibuat dengan cara bakteri diambil sebanyak $1 \mathrm{ml}$ dari stock dan dicampurkan dalam $9 \mathrm{ml}$ aquades steril dan dihomogenkan (pengenceran pertama). Diambil sebanyak 1 $\mathrm{ml}$ dari larutan $10^{-1}$ dan dilarutkan kedalam $9 \mathrm{ml}$ aquades steril dan dihomogenkan maka didapat larutan $10^{-2}$ (pengenceran kedua). Diambil kembali $1 \mathrm{ml}$ dari larutan $10^{-2}$ dan dilarutkan kedalam aquades steril dan dihomogenkan maka didapat larutan $10^{-3}$ (pengenceran ketiga). Hal ini dilakukan hingga pengenceran keenam (larutan $10^{-6}$ ).

\section{Pembuatan Variabel Konsentrasi}

Disiapkan sampel ekstrak induk 100\%, larutan induk dibuat dengan mencampurkan 30 gram ekstrak kulit Gnetum gnemon dan $30 \mathrm{ml}$ aquades steril kemudian dikocok hingga homogen. Selanjutnya dibuat seri konsentrasinya yaitu 25\%, 50\%, 75\% dan kontrol positif dengan menggunakan antibiotik tetrasiklin $10 \mathrm{ppm}$.

\section{Uji Konsentrasi Hambat Minimum (KHM)}

Stok bakteri yang sudah diencerkan 10-6 dan ekstrak kulit biji melinjo yang dengan beberapa konsentrasi $(10 \%, 15 \%, 20 \%$ dan
$25 \%)$ di tuang kedalam cawan petri steril dengan banyaknya bakteri $0,2 \mathrm{ml}$ dan ekstrak $1 \mathrm{ml}$. Selanjutnya dipanaskan media agar hingga mendidih dan didinginkan. Setelah dingin media agar dituang kedalam cawan petri yang sudah berisi bakteri dan ekstrak kulit biji melinjo selanjutnya dihomogenkan dan diinkubasi selama $1 \times 24$ jam dengan suhu $30^{\circ}-35^{\circ} \mathrm{C}$. Setelah masa inkubasi ilakukan pengamatan KHM yang ditentukan dari tidak adanya pertumbuhan bakteri uji pada media agar.

\section{Uji Diameter Daerah Hambat (DDH)}

Kertas cakram (diameter $6 \mathrm{~mm}$ ) dimasukkan ke dalam ekstrak kulit biji melinjo dengan masing-masing konsentrasi diambil sebanyak $2 \mathrm{ml}$, kertas cakram tersebut direndam dalam ekstrak kemudian disimpan terlebih dahulu dipermukaan petri steril dan dimasukan kedalam oven dengan suhu $50^{\circ} \mathrm{C}$ selama 24 jam. Setelah mengering kertas cakram diletakkan di atas medium NA yang telah diinokulasi bakteri uji dengan cara tuang. Masing- masing sampel uji diinkubasi dalam inkubator dengan suhu $30-35^{\circ} \mathrm{C}$ selama 24 jam, kemudian dihitung zona hambat yang terbentuk.

\section{Perhitungan Rendemen}

Rendemen ekstrak total uji dihitung dengan membandingkan berat ekstrak yang dihasilkan dan berat awal simplisia. Sedangkan rendemen serbuk kering kulit biji melinjo diuji untuk membandingkan berat simplisia dan berat basah awal. Rumusnya adalah:

$$
\begin{aligned}
& \text { Rendemen Ekstrak }=\frac{\text { Bobot Ekstrak }}{\text { Bobot Simplisia }} \times 100 \% \\
& \text { Rendemen Serbuk }=\frac{\text { Bobot Simplisia }}{\text { Bobot Basah }} \times 100 \%
\end{aligned}
$$

\section{Uji Fitokimia}

\section{a. Flavonoid}

Sebanyak 0,5 g serbuk simplisia ditambahkan $10 \mathrm{ml}$ air panas, didihkan selama 10 menit dan disaring dalam keadaan panas, kedalam $5 \mathrm{ml}$ filtrat ditambahkan 0,1 
g serbuk magnesium dan $1 \mathrm{ml}$ asam klorida pekat dan $2 \mathrm{ml}$ amil alkohol, dikocok dan biarkan memisah. Flavonoid positif jika terjadi warna merah, kuning dan jingga pada lapisan amil alkohol (Depkes RI, 1989).

\section{b. Saponin}

Sebanyak 0,5 g serbuk simplisia dimasukan kedalam tabung reaksi, ditambahkan $10 \mathrm{ml}$ air panas, dinginkan kemudian dikocok selama 10 detik, jika terbentuk busa yang stabil tidak kurang dari 10 menit dan tidak hilang dengan penambahan 1 tetes asam klorida $2 \mathrm{~N}$ menunjukkan adanya saponin (Depkes RI, 1989).

\section{c. Tanin}

Sebanyak 0,5 g serbuk simplisia disaring dengan $10 \mathrm{ml}$ air suling, filtratnya diencerkan dengan air sampai tidak berwarna. Larutan diambil sebanyak $2 \mathrm{ml}$ dan ditambahkan 1-2 tetes pereaksi besi (III) klorida $1 \%$. Jika terjadi warna hijau, biru atau kehitaman menunjukkan adanya tannin (Harborne, 1987).

\section{d. Triterpenoid}

Asam asetat anidrat $2 \mathrm{ml}$ ditambahkan pada $1 \mathrm{ml}$ ekstrak kulit biji melinjo kemudian ditambahkan $2 \mathrm{ml}$ asam sulfat pekat. Adanya triterpenoid ditandai dengan perubahan warna dari violet menjadi biru atau hijau (Sumiyati, 2014).

\section{HASIL DAN PEMBAHASAN \\ Hasil Ekstraksi Kulit Biji Melinjo}

Dari hasil ekstraksi kulit biji melinjo diperoleh ekstrak cair berwarna merah tua setelah penyaringan, kemudian menjadi berwarna merah tua pekat setelah dievaporasi dengan menggunakan rotary evaporator dengan tujuan untuk memisahkan antara pelarut dengan senyawa aktif yang terkandung di dalam kulit biji melinjo. Ekstrak yang dihasilkan dari proses maserasi ditimbang massanya dan didapatkan ekstrak kental seberat 55,8 gram.

Pada penelitian ini digunakan pelarut jenis etanol 96\% karena etanol merupakan pelarut organik yang bersifat polar. Kulit biji melinjo selain mengandung komponen karotenoid, juga rnengandung komponen lain seperti senyawa-senyawa fenolik dan flavonoid yang bersifat polar. Oleh karena itu penggunaan pelarut etanol juga dapat melarutkan sebagian besar senyawasenyawa fenolik dan flavonoid yang terkandung dalam kulit biji melinjo (Siregar $\mathrm{dkk}, .2009$ ).

Kadar air yang diperoleh menunjukkan hasil 7,5\%, hasil ini sesuai dengan pernyataan dari Depkes RI (2000) bahwa penimbangan bobot sampel sebelum oven dan setelah pengovenan tidak lebih dari $0,25 \%$. Faktor-faktor yang mempengaruhi kadar air yaitu suhu pengeringan, waktu pengeringan dan luas permukaan bahan.

Hasil Rendemen Ekstrak kulit biji melinjo sebesar 18,6\% menunjukkan keefektivan pada saat ekstraksi. Karena semakin besar nilai rendemennya maka semakin efektif pula proses ekstraksinya. Hal ini dipengaruhi oleh lamanya ekstraksi, jenis pelarut yang digunakan sebagai penyari, ukuran partikel simplisia, metode dan lamanya ekstraksi. Sedangkan hasil rendemen serbuk menunjukan hasil $37 \%$.

\section{Uji Konsentrasi Hambat Minimum (KHM) Ekstrak Kulit Biji Gnetum gnemon Terhadap Pertumbuhan Salmonella enteritidis}

Pada Gambar 1. terlihat bahwa bakteri masih dapat tumbuh pada perlakuan dengan konsentrasi ekstrak 10\%, $15 \%$ dan $20 \%$, namun pada perlakuan konsentrasi ekstrak sebesar $25 \%$, pertumbuhan bakteri mulai menurun. Hal ini terlihat dari pertumbuhan bakteri yang sangat sedikit dibandingkan dengan pertumbuhan bakteri pada perlakuan konsentrasi sebesar 10\%, $15 \%$ dan $20 \%$. Pertumbuhan bakteri mulai menurun apabila kandungan nutrisi dalam media pertumbuhan mulai menipis, demikian pula faktor lingkungan seperti terkontaminasi atau tidaknya media uji dan senyawa aktif yang terkandung dalam ekstrak.

Hasil pengujian KHM selengkapnya tersaji pada Gambar 1. 

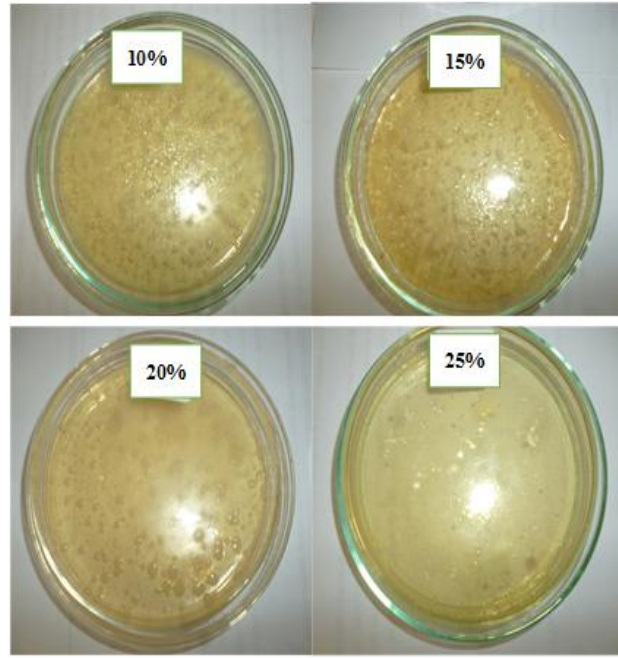

Gambar 1. KHM ekstrak kulit biji Gnetum gnemon pada konsentrasi $25 \%$

\section{Uji Diameter Daerah Hambat (DDH)}

Hasil Uji Diameter Daerah Hambat (DDH) tersaji pada Tabel 1.

Tabel 1. Rata-rata Diameter Daerah Hambat (DDH) Ekstrak Kulit Biji Melinjo Terhadap Salmonella enteritidis

\begin{tabular}{|c|c|}
\hline $\begin{array}{c}\text { Konsentrasi ekstrak } \\
(\%)\end{array}$ & $\begin{array}{c}\text { Diameter Daerah } \\
\text { Hambat }(\mathrm{mm})\end{array}$ \\
\hline $25 \%$ & $7,4^{\mathrm{a}}$ \\
\hline $50 \%$ & $8,6^{\mathrm{a}}$ \\
\hline $75 \%$ & $10,3^{\mathrm{a}}$ \\
\hline Kontrol $(+)$ & $22,3^{\mathrm{b}}$ \\
\hline
\end{tabular}

Dari hasil uji aktivitas ekstrak kulit melinjo terhadap bakteri Salmonella enteritidis diperoleh rata-rata DDH berturutturut pada perlakuan dengan konsentrasi $25 \%$ (7,4 mm), 50\% (8,6 mm),75\% (10,3 $\mathrm{mm})$ dan kontrol (22,3 $\mathrm{mm})$.

Dari hasil pengujian ini tampak bahwa DDH tertinggi diperoleh pada perlakuan dengan konsentrasi ekstrak sebesar $75 \%$. Dari tabel diatas terlihat bahwa semakin tinggi konsentrasi ekstrak maka zona hambat yang terbentuk akan semakin besar sehingga dapat dikatakan bahwa aktivitas senyawa aktif dalam ekstrak kulit biji melinjo semakin tinggi, dan menyebabkan pertumbuhan bakteri semakin sedikit. Dapat dikatakan bahwa bakteri Salmonella enteritidis sensitif terhadap senyawa aktif yang terkandung dalam ekstrak kulit biji melinjo.

Sensitifitas suatu bakteri dapat ditentukan pula dari KHM suatu ekstrak terhadap pertumbuhan bakteri tersebut. Dari Gambar 1. diperoleh KHM ekstrak dalam menghambat pertumbuhan bakteri Salmonella enteritidis yaitu pada perlakuan konsentrasi ekstrak sebesar 25\%, sementara zona hambat yang terbentuk sebesar 7,4 $\mathrm{mm}$. Dari hasil pengamatan ini dapat dikatakan bahwa konsentrasi ekstrak sebesar $25 \%$ efektif menghambat pertumbuhan bakteri Salmonella enteritidis, tetapi perlakuan dengan ekstrak sebesar $75 \%$ membentuk zona hambat terbesar yaitu 10,3 $\mathrm{mm}$ dan dapat dikatagorikan mempunyai aktivitas antimikroba tingkat sensitifitas sedang. Hal ini sesuai dengan pernyataan Prawira (2013) yaitu aktivitas antimikroba memiliki diameter zona hambat $>12 \mathrm{~mm}$ dikategorikan memilki tingkat sensitifitas tinggi, dikategorikan sensitifitas sedang jika memiliki diameter zona hambat $9-12 \mathrm{~mm}$, dimeter zona hambat 6-9 $\mathrm{mm}$ dikegorikan sensitifitas rendah, sedangkan apabila diameter zona hambat $<6 \mathrm{~mm}$ maka dikatakan resisten.

Ekstrak kulit melinjo dikatakan mempunyai aktivitas antimikroba tingkat sedang diduga karena kurangnya senyawa bioaktif yang terkandung dalam ekstrak. Dari hasil pengamatan yang telah dilakukan, bahwa semakin tinggi konsentrasi ekstrak yang digunakan menunjukkan peningkatan daya hambat yang lebih besar. Kandungan senyawa bioaktif yang ada pada kulit melinjo adalah flavonoid, tannin, saponin dan triterpenoid. Menurut Dewi (2011) flavonoid dan tannin bekerja dengan merusak dan menembus dinding sel. Sedangkan Saponin dapat meningkatkan permeabilitas membran sehingga dapat menghambat pertumbuhan mikroba dan bahkan menyebabkan lisis.

Selain kurangnya senyawa bioaktif yang terkandung dalam ekstrak, bakteri Salmonella enteritidis juga merupakan bakteri gram negatif yang memiliki lapisan

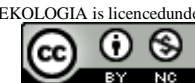


lipopolisakarida pada dinding selnya, sehingga memiliki sistem seleksi terhadap zat- zat asing dilingkungannya, maka dari itu daya serap terhadap ekstrak kulit melinjo rendah (Rahmawati dan Bintari, 2014).

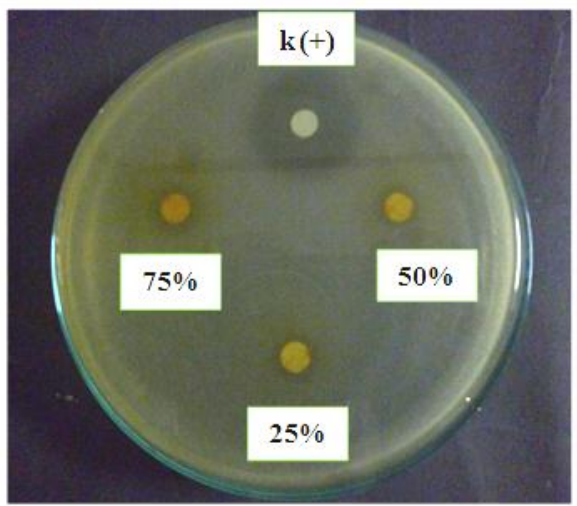

Gambar 2. Uji Diameter Daya Hambat Ekstrak Kulit Biji Melinjo Terhadap Salmonella enteritidis

\section{Pengujian Fitokimia Ekstrak Kulit Biji Melinjo}

Pada tabel 2. senyawa yang terkandung didalam ekstrak kulit melinjo yang paling banyak adalah flavonoid dan tannin dengan adanya perubahan warna yang sangat jelas pada saat pengujian. Diketahui bahwa flavonoid mempunyai kecendrungan untuk mengikat protein, sehingga mengganggu proses metabolisme (Praptiwi, 2010). Sedangkan senyawa tanin bekerja dengan cara membentuk ikatan yang stabil dengan protein sehingga terjadi koagulasi protoplasma bakteri (Nikham dan Basjir, 2012).

Dari hasil uji Fitokimia ekstrak kulit biji Gnetum gnemon diperoleh senyawa aktif golongan flavonoid, saponin, triterpenoid dan tannin. Diketahui bahwa flavonoid, saponin dan tannin memiliki sifat antibakteri. Hal ini terbukti dengan adanya zona hambat yang dibentuk oleh bakteri Salmonella enteritidis pada perlakuan konsentrasi ekstrak $75 \%$ sebesar 10,3 mm. Pengamatan pada flavonoid, tannin dan triterpenoid didasarkan pada reaksi pembentukan warna, sedangkan uji saponin berdasarkan pembentukan busa. Hasil selengkapnya pada Tabel 2.
Tabel 2. Hasil Identifikasi Golongan Senyawa Fitokimia Kulit Biji Melinjo Uji Indikasi Hasil Fitokimia

\begin{tabular}{ccc} 
Flavonoid & $\begin{array}{c}\text { Terjadi warna merah, } \\
\text { kuning dan jingga pada } \\
\text { lapisan amil alkohol }\end{array}$ & $(++)$ \\
\hline Saponin & $\begin{array}{c}\text { Ada busa yang } \\
\text { bertahan } \pm 10 \text { menit } \\
\text { (stabil) dan busa tidak } \\
\text { hilang setelah } \\
\text { penambahan 1 tetes }\end{array}$ & $(+)$ \\
& HCl 2N & \\
\hline Tanin & $\begin{array}{c}\text { Terjadi warna hijau, } \\
\text { biru atau kehitaman }\end{array}$ & $(++)$ \\
\hline Triterpenoid & $\begin{array}{c}\text { Perubahan warna dari } \\
\text { violet atau merah } \\
\text { menjadi hijau }\end{array}$ & $(+)$ \\
& & \\
\hline
\end{tabular}

Keterangan:

Tanda (++): Menunujukan adanya senyawa yang lebih banyak terkandung dalam ekstrak

Tanda (+) : Menunjukan adanya kandungan senyawa yang terkandung dalam ekstrak namun hanya sedikit

\section{KESIMPULAN}

Berdasarkan hasil penelitian yang telah dilakukan mengenai aktivitas ekstrak kulit biji melinjo sebagai penghambat pertumbuhan Salmonella enteritidis maka dapat ditarik kesimpulan bahwa: Konsentrasi Hambat Minimum (KHM) ekstrak kulit biji melinjo yaitu pada perlakuan konsentrasi 25\%. Ekstrak kulit biji melinjo memiliki aktivitas antibakteri paling tinggi terhadap Salmonella enteritidis pada konsentrasi $75 \%$ dengan diameter daerah hambat sebesar 10,3 $\mathrm{mm}$ dan dikatagorikan mempunyai daya antimikroba tingkat sensitifitas sedang. Hasil uji fitokimia yang telah dilakukan diperoleh senyawa dari golongan flavonoid, saponin, tannin dan triterpenoid.

\section{DAFTAR PUSTAKA}

Ariyanti dan Supar. (2005). Deteksi Antibodi terhadap Salmonella enteritidis dan Salmonella pullorum pada Ayam dengan ELISA Menggunakan Antigen Somatik dan Flagela. Laboraturium 
Bakteriologi Balai besar Penelitian Veteriner. 8(3): 111-118.

Depkes RI. (1989). Materia Medika Indonesia Jilid V. Jakarta.

Depkes RI. (2000). Parameter Standar Umum Ekstrak Tumbuhan Obat cetakan pertama. Jakarta.

Dewi. (2011). Aktivitas Antioksidan dan Antimikroba Ekstrak Melinjo (Gnetum gnemon L.) Terhadap Mikroba Pembusuk. Fakultas Pertanian Universitas Sebelas Maret, Surakarta.

Harborne, J.B. (1987). Metode Fitokimia: Penuntun Cara Moderen Menganalisis Tumbuhan, edisi kedua. Bandung: Penerbit ITB.

Mukhlisah. (2014). Pengaruh Level Ekstrak Daun Melinjo (Gnetum gnemon Linn) dan Lama Penyimpanan yang Berbeda Terhadap Kualitas Telur Itik, Fakultas Peternakan Universitas Hasanudin, Makasar.

Nikham dan Basjir. (2012). Uji Bahan Antibakteri dari Buah Mahkota Dewa (Phaleria macrocarpa (Scheff) Boerl.) Hasil Iridasi Gamma dan Antibiotik Terhadap Bakteri Patogen. Prosiding Pertemuan Ilmiah Ilmu Pengetahuan dan Teknologi Bahan.

Prawira. (2013). Daya Hambat Dekok Daun Kersen (Muntingia calabura L.) Terhadap Pertumbuhan Bakteri Staphylococcus aureus Penyebab Penyakit Masitis pada Sapi Merah. Fakultas Peternakan Universitas Brawijaya.

Praptiwi. (2010). Uji Aktivitas Antibakteri Ekstrak Kulit Buah Manggis (Garcinia mangostana Linn). Balai Besar Penelitian Veteriner. Bogor. Vol. XX(2).

Rahardjo. (2012). Efektivitas Jeruk Nipis dalam Menurunkan Bakteri Salmonella dan Escherchia coli pada Karkas Ayam Broiler. Universitas Jenderal Sudirman. 2(3).

Rahmawati dan Bintari. (2014). Studi Aktivitas Antibakteri Sari Daun Binahong (Anredera cordifolia) Terhadap Pertumbuhan Bacillus cereus dan Salmonella enteritidis. Fakultas MIPA, Universitas Negeri Semarang. Unnes Journal of Life Science 3(2). (2Juli014).

Silaban. (2009). Skrining Fitokimia dan Uji Aktivitas Antibakteri dari Kulit Buah Sentul (Sandoricun Koetjape (Burn.f.)Merr) Terhadap Beberapa Bakteri Secara In vitro. Fakultas Farmasi Universitas Sumatera Utara. Medan.

Siregar, Cornelia, Ermiziar dan Raskita. (2009). Studi Kandungan Karotenoid, Vitamin C, dan Aktivitas Antioksidan Kulit Melinjo (Gnetum gnemon L). Jurusan Teknologi Universitas Pelita Harapan, Tanggerang. Banten.

Sumiyati. (2014). Efektivitas Ekstrak Padina australis sebagai antibakteri E.Coli penyebab penyakit diare. Fakultas Matematika dan Ilmu Pengetahuan Alam Universitas Pakuan. Bogor.

Usmiati. (2010). Pengawetan Daging Segar dan Olahan. Balai Besar Penelitian dan Pengembangan Pascapanen Pertanian Kampus Penelitian Pertanian. Bogor. 